\title{
Dynamic Capabilities related Implementation Skills for Internet of Things Solutions in the Digital Economy
}

\author{
Mashood Ahmad \\ University of Bamberg, \\ Germany \\ mashood.ahmad@uni- \\ bamberg.de
}

\author{
Marcel Papert \\ University of Bamberg, \\ Germany \\ marcel.papert@uni-bamberg.de
}

\author{
Alexander Pflaum \\ University of Bamberg, \\ Germany \\ alexander.pflaum@uni- \\ bamberg.de
}

\begin{abstract}
The digital economy is shaped by the increasing implementation of Internet of Things (IoT) solutions. These solutions enable the vertical integration of smart objects into existing information systems, thereby realizing the vision that every physical object obtains a digital identity. However, dynamic characterizes the technologically driven IoT market and requires related capabilities from enterprises, aiming to provide IoT solutions. Therefore, the purpose of this study is to explore which DC are sufficient for the implementation of effective IoT solutions by taking a DC perspective. Based upon an empirical survey of IoT solution integrators and an exploratory fuzzy-set qualitative comparative analysis (fsQCA), our results show that the combination of differentiation strategy, technological and entrepreneurial orientation enables the implementation of effective IoT solutions. The results further provide a theoretical contribution for a DC discussion in the IoT research area and, offer implementation recommendations for enterprises about how to manage IoT solution implementation.
\end{abstract}

\section{Introduction}

With the ongoing digitalization [1] it is becoming increasingly relevant for enterprises in the Internet of Things (IoT) market to continuously modify and, if necessary, completely revamp their activities [2], in order to stay competitive or gain competitive advantage. In this regard, the IoT is defined as "a dynamic global network infrastructure with selfconfiguring capabilities based on standard and interoperable communication protocols where physical and virtual 'Things' have identities, physical attributes, and virtual personalities and use intelligent interfaces, and are seamlessly integrated into the information network" [3].

It is especially important for IoT solution integrators, who operate in a fast-changing environment [4], to handle the challenges that arise with new technologies [5]. IoT solution integrators are enterprises that act in the IoT market and implement IoT solutions (services). Additionally, industry boundaries become blurred so that enterprises need to diversify and move into related areas [6]. The questions for these enterprises are: How can they position themselves, identify changes in the environment and prepare for these changes [7]? How can they drive technological advancement [8], how effective is their business partner work in alliances and thus how can they enjoy competitive advantage over competing enterprises through greater alliance success [9]? Forming such alliances for strategic reasons in dynamic business environments, especially for the realization of complex IoT solutions, is inherent in the establishment of a business ecosystem [10, 45, 46, 47, 48].

The aforementioned references emphasize that these questions need to be answered, especially with the theoretical lens of the dynamic capabilities approach. In this context, DC-related skills support IoT solution integrators in implementing effective solutions and, therewith, the realization of competitive advantage. In order to explore which DC-related skills support the implementation of an effective IoT solution the authors will address the following research question: Which configurations of dynamic capabilities related skills lead to the implementation of an effective IoT solution?

By adopting the dynamic capabilities approach, this study provides combinations of dynamic capabilities related skills that support the implementation of an effective IoT solution. To the best of our knowledge, this study is the first to analyze the implementation of IoT solutions from a dynamic capabilities perspective, 
and it therefore proposes a realization of competitive advantage through the implementation of effective IoT solutions. Moreover, this study applies a relatively new methodology (fuzzy-set qualitative comparative analysis) in the IoT research field, and thus supports its dissemination in management-related studies [10].

In the following chapter the authors provide an introduction to dynamic capabilities (DC) and a critique of the resource-based view (RBV). In Chapter 3 the authors identify DC skills, which will be the best fit for answering the aforementioned questions arising from IoT markets' fast-changing business environment. Chapter 4 explains the research methodology. Chapter 5 presents the results of our study. Chapter 6 discusses the results and elaborates a conclusion.

\section{Resource-based view and its extension to dynamic capabilities view}

To understand the dynamic capabilities view (DCV), it is necessary to understand its history, which is embedded in the resource-based view (RBV). Following an introduction to RBV, Chapter 2 explains the DCV through definitions and its classes.

\subsection{Resource-based view}

In the $\mathrm{RBV}$, resources are the tangible and intangible assets, broadly defined, that the firm can develop and control [11], or alternatively "an asset or input to production (tangible or intangible)" [12]; they become valuable when they are applied to their specific market context [13]. This means that applying the right resources in the right market can lead to competitive advantage. To achieve competitive advantage the resources must have some characteristics that can be defined as valuable, rare, difficult to imitate and not substitutable [14]. These characteristics are also known as the VRIN characteristics [15, 16, 17]. Even though the RBV was enriched during the years following its emergence in the strategic management discourse, it was still unable to explain how to develop and maintain resources over time [18]. Moreover, RBV is static and therefore not useful for explaining competitive advantage in a changing environment [19]. Against this background, the dynamic capabilities (DC) approach addresses this problem [20].

\subsection{Dynamic capabilities view}

Since Teece et al.'s influential article in 1997 created interest in DC as a strategic management discipline, many authors have developed their own definition of
DC [21]. Authors also identify different types of DC [22]. "Some are used to integrate resources, some to reconfigure resources, some are about creating new resources, while others are about shedding resources" [ibid.]. Since they can be seen as "adaptions of Teece et al.'s original definition" [ibid.], the authors have simply described any changes in the wording of Teece's definitions during the last 20 years. In [18] DC is defined as the "firm's ability to integrate, build, and reconfigure internal and external competences to address rapidly changing environments". In [23] Teece speaks of DC as the ability to "sense and seize opportunities quickly and proficiently". In the same year Eisenhardt and Martin define DC as "organizational and strategic routines by which the firms achieve new resource configurations" [24]. Teece refers to it as the extension of "shaping the environment" [25].

The definition found in $[2,11,26]$, which can be seen as his latest definition of dynamic capabilities, are still based on [18] and defined as competences of higher-level determining an enterprises ability to "integrate, build, and reconfigure internal and external resources/competences to address, and possibly shape, rapidly changing business environments"[2].

Reading these definitions and processing them, it becomes clear that DC is not just unplanned problemsolving activities [27, 28, 29], but rather "metacompetences that transcend operational competence" [30]. They have to be built and repeatable, in other words, trained skills, in order not to become ad hoc problem-solving activities. Moreover, DC is not a resource in itself. They are processes, which impact resources [22] or can be seen as "a transformer for converting resources into improved performance" [31].

2.2.1 Classes of dynamic capabilities. It has been demonstrated as practical to think of DC as differentiated into three classes [32]. For this reason, in this chapter the authors discuss the three classes of DC, namely sensing, seizing and transforming, as the higher-level competencies that enable enterprises to stay competitive.

2.2.2. Sensing. Sensing can be described as the "identification and assessment of an opportunity" [2]. It enables the enterprise to realize where opportunities are and to mobilize the necessary resources [33]. Moreover, the conceptualization and development of new business models can be counted in this class of DC [ibid.]. Enterprises engaging in volatile or fastchanging environments should therefore be using this capability as part of their strategy, often in order to stay competitive or to gain competitive advantage. It is clear that with changing environments enterprises need 
to monitor the market and be ready to seize the opportunity.

2.2.3. Seizing. Seizing refers to addressing the realized opportunity and capturing value from it [2]. This can be done by investing in these opportunities [34] and creating a new product, process or service [21]. Therefore, it is about making the right decisions in a changing environment, which leads to decisions being made in uncertain conditions [35]. This means that the enterprise needs processes, which enable it to evaluate sensed opportunities and eventually to change the existing strategy [36]. Just as the opportunities that are addressed change, so the enterprise needs to change its resource base, which it can do through transforming.

2.2.4. Transforming. "Transforming refers to the continuous renewal and modification" [21] of the tangible or even intangible resource base. The enterprise has to be reconfigured, because of the changing market environment and/or technology. The continuous renewal of the enterprise leads to an agile enterprise, which can generate economic surplus over time [30]. Particularly in fast-changing environments, transforming becomes very important, not only to adapt to the surrounding ecosystem, but also sometimes to transform the ecosystem itself [2].

\section{Dynamic capabilities related skills of IoT solution integrators}

As explained in Chapter 2, the DCV demands skills that should ensure competitive advantage for enterprises. By transferring this line of thinking to the IoT market, IoT solution integrators need to possess skills that enable the implementation of effective IoT solutions, ultimately resulting in effectivity gains for the users of these IoT solutions. Through these effectivity gains, IoT solution integrators are able to differentiate themselves in the IoT market and, therewith, to obtain competitive advantage [37]. In this context, the following sections theoretically discuss dynamic capabilities related skills that support the implementation of IoT solutions in order to realize effectivity gains.

In the context of the DCV, Teece emphasizes an entrepreneurial management that is about "figuring out the next big opportunity or challenge" [2]. Therefore, it is the responsibility of IoT solution integrators to establish an entrepreneurial orientation skill that allows solution integrators to deal with the IoT market and to cope with the challenges accompanying the implementation of IoT solutions in order to realize effectivity gains for users. Entrepreneurial orientation can therefore be regarded as a DC-related skill, which results in an overall innovative and proactive attitude $[38,39]$.

Because of blurred industry boundaries, which become existent through digitalization [1, 6], IoT solution integrators need to ask themselves how they will differentiate themselves for competitive advantage in relation to the DCV. At this point, a differentiation strategy would enable "the enterprise to position itself for making the right products and targeting the right markets to address the consumer needs" [2]. Thus, the authors regard a skill for implementing a differentiation strategy as being important for solution integrators in the IoT market in order to realize effectivity gains for users.

Besides its technology focus, the IoT market is characterized by an increasing service aspect of IoT solutions $[40,41]$. As a result of the increasing service aspect, solution integrators need to spot external technological opportunities [42]. Consequently, IoT solution integrators should consider technology orientation in order to implement effective IoT solutions. Such a skill leads to the development of innovative and superior solutions [43] that support the differentiation and realization of competitive advantage [37] in relation to the DCV.

As some authors have already stated, dynamic capabilities are not ad hoc reactions to market changes [27, 28, 29], IoT solution integrators should also conduct structured development processes for their IoT solutions. In particular, enterprises that try to make the transition from a product- to a service-oriented enterprise fail to develop superior solutions because "manager[s] have tended to apply an unsuitable product development approach to the service development process" [20]. In this context, a service engineering skill with models and methods [44] can support integrators in the systematic development of effective IoT solutions. Therewith, IoT solution integrators are able to design the solutions that customers are demanding.

As a result of the technology focus, the implementation of IoT solutions is complex. At this point, IoT solution integrators are advised to establish ecosystems that support the implementation of IoT solutions with cooperation partners $[10,45,46,47,48]$. For this to happen, integrators need to align their resources, including the assessment of "when and how the enterprise ought to form alliances with other organizations" [2]. To make an alliance work in an implementation project, enterprises should ensure effective project collaboration for valuable solutions [ibid.]. This includes enterprises and cooperation partners taking care of their respective responsibilities and maintaining a productive business relationship. 
Therefore, IoT solution integrators are advised to ensure alliance orientation in an implementation project in order to realize effective IoT solutions. Such effective solutions, in turn, allow differentiation possibilities in the IoT market and, therewith, the realization of competitive advantage.

The aforementioned discussion shows that the implementation of an effective IoT solution requires different dynamic capabilities related skills. The authors hypothesize that these skills should not be regarded in isolation from one another for the implementation of effective IoT solutions and, therewith, the realization of competitive advantage in the IoT market. Against this background, the purpose of this study is to show how these skills relate to effectivity gains through an implemented IoT solution. For this reason, the authors want to explore whether possible combinations of dynamic capabilities related skills are sufficient for effectivity gains through an implemented IoT solution. Therefore, this study entails a configurational character that is depicted in Figure 1, a Venn diagram [57]. Figure 1 shows our conceptual model, with all the possible combinations of the different DC-related skills discussed and the outcome in question, that is, effectivity gains through an implemented IoT solution. In order to analyze whether, and which, combinations of dynamic capabilities related skills are sufficient for effectivity gains, the authors conducted an exploratory fuzzy-set qualitative comparative analysis (fsQCA) [57].

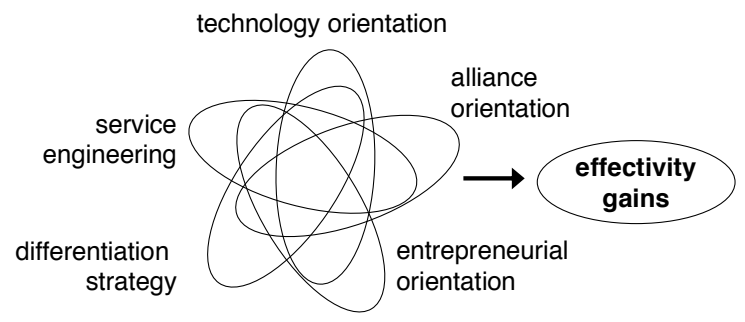

Figure 1. Conceptual model

\section{Methodology}

The authors conducted an empirical survey among management executives with expert knowledge (key informants) from IoT solution integrators. The related firms are working in the information service sector, were identified through a proprietary database from an address service provider and are covering the provision of IoT solutions for a broad range of industries, such as automotive, manufacturing, retail, finance, energy and the building industry. The authors collected the relevant data through a paper and pencil survey. For this reason, a questionnaire, together with a cover letter, were sent to the key informants to invite them to participate in the study. Through this approach, the authors gained 53 valid responses, whereby the average firm provides IoT solution implementations for 6.91 years and conducts 4.893 IoT solution implementation projects.

Non-response bias was controlled in relation to the recommendations from [49]. Therefore, the authors compared the data of variables from early and late respondents (T-Test for independent samples). However, the results indicated no differences in the items, meaning that the respondents were representative of the population.

This study collected data through single-item and multiple-item constructs related to our theoretical discussion. The execution of service engineering for the implementation of an IoT solution was measured by a single item because of its manifest character. The authors measured differentiation strategy using the items of [50] and [51]. In order to measure entrepreneurial orientation, the authors used the items from [52]. Furthermore, this study applied the items from [53] and [54] to measure technology orientation. Alliance orientation was measured with the items based on [55]. Finally, our study captures effectivity gains through an implemented IoT solution in relation to the items from [56]. Table 1 provides an overview of the construct measures and the factor loadings of the respective items. With regard to Table 1, all factor loadings are high and therefore exhibit validity. Moreover, the scores of the multiple-item constructs for Cronbach's Alpha (CA) exceed .7 [66], for Composite Reliability (CR) .6 and for Average Variance Extracted (AVE) .5 [67]. All single- and multiple-item constructs were captured through a seven-point Likert-type rating scale. In detail, the Likert-type rating scale for service engineering ranges from $1=$ "never" to $7=$ "very often". Technology orientation, entrepreneurial orientation and effectivity gains were measured through a 7-point Likert-type rating scale from $1=$ "completely disagree" to $7=$ "completely agree", whereas differentiation strategy was measured through a 7-point Likert-type rating scale from 1 = "nothing at all" to $7=$ "very intensive". Finally, a 7-point Likert-type rating scale from $1=$ "with no degree" to $7=$ "in a very high degree" was used to measure alliance orientation. 
Table 1. Information on construct measures

\begin{tabular}{|c|c|}
\hline Construct measures & $\begin{array}{l}\text { Factor } \\
\text { loadings }\end{array}$ \\
\hline $\begin{array}{l}\text { Differentiation strategy } \\
(\mathrm{CA}=.79 ; \mathrm{CR}=.86 ; \mathrm{AVE}=.61)\end{array}$ & \\
\hline $\begin{array}{l}\text { Creating superior customer value } \\
\text { through services accompanying the } \\
\text { products. }\end{array}$ & .713 \\
\hline $\begin{array}{l}\text { Offering highly } \\
\text { differentiated/innovative products. }\end{array}$ & .731 \\
\hline New product development. & .787 \\
\hline $\begin{array}{l}\text { Competitive advantage through } \\
\text { superior products. }\end{array}$ & .883 \\
\hline $\begin{array}{l}\text { Entrepreneurial orientation } \\
(\mathrm{CA}=.86 ; \mathrm{CR}=.9 ; \mathrm{AVE}=.7)\end{array}$ & \\
\hline $\begin{array}{l}\text { We actively prepare for the changes } \\
\text { brought by IoT solutions. }\end{array}$ & .753 \\
\hline $\begin{array}{l}\text { We are ready to face the challenges } \\
\text { brought by IoT solutions. }\end{array}$ & .860 \\
\hline $\begin{array}{l}\text { We actively build our capacity to } \\
\text { react effectively to market changes. }\end{array}$ & .849 \\
\hline $\begin{array}{l}\text { We ensure that our advantages can } \\
\text { withstand changes in the industry. }\end{array}$ & .866 \\
\hline $\begin{array}{l}\text { Technology orientation } \\
(\mathrm{CA}=.84 ; \mathrm{CR}=.89 ; \mathrm{AVE}=.61)\end{array}$ & \\
\hline $\begin{array}{l}\text { We are very active in developing new } \\
\text { technologies. }\end{array}$ & .799 \\
\hline $\begin{array}{l}\text { Our product development } \\
\text { programmes are more ambitious than } \\
\text { those of our competitors. }\end{array}$ & .795 \\
\hline $\begin{array}{l}\text { We have better technological } \\
\text { knowledge than our competitors. }\end{array}$ & .814 \\
\hline $\begin{array}{l}\text { We intend to develop new } \\
\text { technologies in order to respond to } \\
\text { the changing expectations of our } \\
\text { customers. }\end{array}$ & .777 \\
\hline $\begin{array}{l}\text { Our products include high- } \\
\text { technology items. }\end{array}$ & .716 \\
\hline $\begin{array}{l}\text { Alliance orientation } \\
(\mathrm{CA}=.88 ; \mathrm{CR}=.92 ; \mathrm{AVE}=.73)\end{array}$ & \\
\hline $\begin{array}{l}\text { The relationship between our firm } \\
\text { and the partner firm has been } \\
\text { productive. }\end{array}$ & .847 \\
\hline $\begin{array}{l}\text { The time and effort spent in } \\
\text { developing and maintaining the } \\
\text { relationship with the partner firm has } \\
\text { been worthwhile. }\end{array}$ & .820 \\
\hline $\begin{array}{l}\text { The partner firm carried out its } \\
\text { responsibilities and commitments } \\
\text { with respect to the project. }\end{array}$ & .873 \\
\hline $\begin{array}{l}\text { Our firm carried out its } \\
\text { responsibilities and commitments } \\
\text { with respect to the project. }\end{array}$ & .879 \\
\hline Service engineering & \\
\hline
\end{tabular}

\begin{tabular}{|l|l|}
\hline (CA = n.a.; CR $=$ n.a.; AVE $=$ n.a. $)$ & \\
\hline $\begin{array}{l}\text { Models, methods and tools of service } \\
\text { engineering for the implementation of }\end{array}$ & 1 \\
IoT solutions. & \\
\hline $\begin{array}{l}\text { Effectivity gains } \\
(\mathrm{CA}=.86 ; \mathrm{CR}=.9 ; \mathrm{AVE}=.63)\end{array}$ & .806 \\
\hline $\begin{array}{l}\text { The functionalities of IoT solutions } \\
\text { adequately meet the requirements of } \\
\text { our jobs. }\end{array}$ & .808 \\
\hline $\begin{array}{l}\text { The IoT solutions always fulfil their } \\
\text { functionalities perfectly. }\end{array}$ & .805 \\
\hline $\begin{array}{l}\text { With the help of IoT solutions, new } \\
\text { and previously impossible IoT } \\
\text { solutions were realized. }\end{array}$ & .747 \\
\hline $\begin{array}{l}\text { Data provided by IoT solutions adds } \\
\text { value to our operations. }\end{array}$ & .809 \\
\hline $\begin{array}{l}\text { The IoT solutions enhance process } \\
\text { transparency and process agility. }\end{array}$ & \\
\hline
\end{tabular}

$\mathrm{CA}=$ Cronbach's Alpha, $\mathrm{CR}=$ Composite Reliability, $\mathrm{AVE}=$ Average Variance Extracted.

In order to explore dynamic capabilities related skills for the implementation of an IoT solution, this study used fsQCA [57]. FsQCA views an outcome (case) in question and its realization as a combination of antecedents (conditions) [57, 58]. Moreover, fsQCA considers the aspect that an outcome in question results not only from one combination of conditions (unifinality) but rather from different possible combinations of conditions (equifinality). In this context, fsQCA regards the relationships between conditions as set relations, whereby the outcome and conditions have to be transformed into fuzzy-set membership scores. These sets are represented on a scale of 0 to 1 and express the degree to which a case, with its outcome, is within, without or part of a set. Based on combinatory logic and algorithmic calculations, the sets are analyzed in order to present combinations of conditions that lead to the outcome in question.

This study conducted fsQCA in three steps: calibration, construction of a truth table and analysis of the truth table $[57,58]$. The software program fs/QCA 2.5 supported the data analysis [59]. In the first step, the authors transformed each multiple-item construct into a composite score. In order to conduct the calibration, the authors defined three necessary anchors for fuzzy-set membership, namely, full membership, full non-membership, and crossover point. With consideration of the 7-point Likert-type rating scale used, the authors set the threshold for full membership to value 6 , for the crossover point to value 4 and for full non-membership to value 2. To avoid unclear fuzzy-set membership scores of .5, the authors added .001 to every construct calibration [58]. 
After calibration, the authors calculated the truth table with fs/QCA 2.5. This truth table lists all possible combinations of conditions that can lead to the outcome in question. Moreover, the truth table lists all empirical representations of conditions that are covered by data [ibid.]. Afterwards, the authors refined the table in terms of frequency and consistency. Frequency shows the empirical cases per row. As the QCA literature does not provide any clear recommendations for a frequency threshold [60], the authors set the frequency threshold to 1 . Therefore, this study includes more than 80 per cent of the cases of our empirical sample, as recommended by [61]. Consistency expresses the degree to which the empirical cases, with their combinations of conditions, represent the outcome in question. The QCA literature recommends the identification of a dip in the consistency scores and emphasizes a minimum consistency threshold of 0.8 [62]. Additionally, users of fsQCA should consider a minimum score for Proportional Reduction of Inconsistency (PRI) of .75 [63]. In our truth table, the authors looked for a dip within the consistency scores and set the minimum acceptable consistency level to .95. Additionally, the authors inspected the PRI scores for the consistent combinations of conditions. Here, our minimal PRI score is 0.94 and therefore above .75 .

The following analysis of the truth table was conducted through the Quine-McCluskey algorithm with the fs/QCA 2.5 software in order to identify combinations of conditions that consistently lead to the outcome in question. Thereby, the algorithm identifies sufficient configurations of conditions that, by definition, realize the outcome [57, 64]. The next chapter presents the results of the truth table analysis.

\section{Results}

This study presents the combinatory effects between the conditions, which represent our DCrelated skills (see Chapter 3), and the outcome in question, as suggested by [65]. Table 2 shows our results, which are derived from the parsimonious and intermediate solutions provided by fs/QCA 2.5 [57, 58]. Thereby, full black circles symbolize the presence of a condition, whereby circles with a cross-out represent its negation. Large circles express core conditions and small circles show peripheral conditions for the outcome in question. In comparison to a peripheral condition, a core condition constitutes a central part of a solution for the outcome in question [58]. White spaces indicate that the related condition is not a matter in the solution. Besides consistency, fs/QCA 2.5 provides coverage scores, namely raw and unique coverage, for each solution in order to assess its empirical relevance. Raw coverage indicates the percentage of membership in the outcome of a configuration, whereas unique coverage indicates the unique percentage of membership in the outcome of a configuration [64].

Our analysis with fs/QCA 2.5 basically identifies three solutions for effectivity gains through IoT solution implementation. The overall solution consistency is .95 and the overall solution coverage is .89. The overall consistency indicates that the solutions identified are highly consistent with the outcome in question. Moreover, the overall coverage expresses that the solutions represent a substantial part for the outcome in question.

Table 2. Combinatory effects identified by fsQCA

\begin{tabular}{|c|c|c|c|}
\hline \multirow[b]{2}{*}{ Conditions } & \multicolumn{3}{|c|}{ Solutions for effectivity gains } \\
\hline & 1 & $2 \mathrm{a}$ & $2 b$ \\
\hline $\begin{array}{l}\text { Differentiation } \\
\text { strategy }\end{array}$ & $\bullet$ & $\otimes$ & $\otimes$ \\
\hline $\begin{array}{l}\text { Entrepreneurial } \\
\text { orientation }\end{array}$ & $\bullet$ & $\otimes$ & $\bullet$ \\
\hline $\begin{array}{l}\text { Technology } \\
\text { orientation }\end{array}$ & C & $\otimes$ & $\otimes$ \\
\hline $\begin{array}{l}\text { Alliance } \\
\text { orientation }\end{array}$ & & $\otimes$ & $\bullet$ \\
\hline $\begin{array}{l}\text { Service } \\
\text { engineering }\end{array}$ & & • & $\otimes$ \\
\hline Consistency & .95 & .98 & .96 \\
\hline Raw coverage & .87 & .05 & .08 \\
\hline $\begin{array}{l}\text { Unique } \\
\text { coverage }\end{array}$ & .80 & .00 & .01 \\
\hline $\begin{array}{l}\text { Overall solution } \\
\text { consistency }\end{array}$ & & .95 & \\
\hline $\begin{array}{l}\text { Overall solution } \\
\text { coverage }\end{array}$ & & .89 & \\
\hline
\end{tabular}

Solution 1 shows a combination of the presence of differentiation strategy, entrepreneurial orientation and technology orientation. Technology orientation represents the core condition in solution 1 , whereas differentiation strategy and entrepreneurial orientation are peripheral conditions accompanying technology orientation. Alliance orientation and service engineering do not matter in this solution (blank spaces). Consequently, IoT solution implementation achieves effectivity gains if a firm emphasizes technology orientation and considers a differentiation strategy and entrepreneurial orientation. The 
consistency of solution 1 is .95 , the raw coverage is .87 and the unique coverage is .8 , respectively.

Solution $2 \mathrm{a}$ includes the negation of differentiation strategy, entrepreneurial orientation, technology orientation, alliance orientation and the presence of service engineering. Differentiation strategy represents the core condition. Thus, IoT solution implementation theoretically achieves effectivity gains if a firm considers service engineering and not differentiation strategy, entrepreneurial orientation, technology orientation and alliance orientation. The consistency score of solution $2 \mathrm{a}$ is .98 , the raw coverage score is .05 and the unique coverage score is .00 , respectively.

Like solution $2 \mathrm{a}$, solution $2 \mathrm{~b}$ contains the negation of differentiation strategy as the core condition. However, solution $2 \mathrm{~b}$ further combines the presence of entrepreneurial orientation and alliance orientation, as well as the negation of technology orientation and service engineering. Thus, IoT solution implementation theoretically achieves effectivity gains if a firm considers entrepreneurial orientation and alliance orientation, but not differentiation strategy, technology orientation and service engineering. Finally, the consistency score of solution $2 \mathrm{~b}$ is .96 , the raw coverage score is .08 and the unique coverage score is .01 , respectively.

\section{Discussion of results and conclusions}

The aim of this study was to extend the body of knowledge on the implementation of IoT solutions in the digital economy. By adopting a DC view, the authors explored how DC-related skills in the context of IoT solution implementation relate to effectivity gains through the solution implemented. However, it should be noted that the DC view is regarded as an approach rather than a theory [11]. The results of our exploratory fuzzy-set qualitative comparative analysis (fsQCA) shows different sufficient combinations of skills that lead to effectivity gains.

Regarding the contributions of our study, the authors identify theoretical and practical issues that advance the current body of knowledge on IoT research. First, we suggest that the implementation of IoT solutions should be considered through a DC view that emphasizes skills that support the implementation of effective IoT solutions and, therewith, the realization of competitive advantage in the IoT market. Second, by using the fsQCA methodology, this study indicates that the combination of differentiation strategy, entrepreneurial orientation and technology orientation in the context of IoT solution implementation leads to effectivity gains. This combination (solution 1 in Table 2) shows a high degree of consistency with the outcome in question and exhibits high empirical relevance due to high raw and unique coverage scores. Furthermore, solutions $2 \mathrm{a}$ and $2 \mathrm{~b}$ also show high consistency scores, but the raw and unique coverage scores are very low. These coverage scores indicate that solutions $2 \mathrm{a}$ and $2 \mathrm{~b}$ do not exhibit empirical relevance. Consequently, the combinations of skills presented by solutions $2 \mathrm{a}$ and $2 \mathrm{~b}$ do not provide an empirical contribution. Thus, this study demonstrates that the interweaving of the DC-related skills for a differentiation strategy, technology orientation and entrepreneurial orientation in the context of IoT solution implementation leads to effectivity gains through the solution. Moreover, technology orientation represents a core condition being more important for achieving effectivity gains than differentiation strategy and entrepreneurial orientation.

During the interpretation of the results the authors registered that there is a great overlap between our dynamic capabilities related skills and the three classes of dynamic capabilities described in Chapter 3, which are recommended for differentiation by [2]. First, we see that entrepreneurial orientation can be related to sensing activities. This is because entrepreneurial orientation is, for example, about being ready to face challenges and build capacity to be able to react effectively to market changes. Second, technology orientation can be related to seizing. This is because enterprises actively develop new technologies, develop ambitious product-development programmes or include high-technology items. Last but not least, differentiation strategy can be related to transforming. This is because differentiation strategy is about securing competitive advantage by creating superior customer value, thorugh superior products and also differentiated/ innovative products, which can only be realized through continuous transforming. This brings us to the argument that it is possible that all three classes of DC have to be utilized and employed often and simultaneously [30].

The results of our study provide recommendations for IoT solution integrators about the relevant skills for the implementation of effective IoT solutions. Practitioners can see what skills they need to develop for the implementation of an IoT solution in the dynamic and technologically driven IoT market. Moreover, our results can be regarded as best practice results because of the high level of consistency with the outcome in question.

However, this study contains some limitations. First, the empirical data is gained from a limited number of IoT solution integrators and has a local focus on Germany. Second, our results focus on DCrelated skills for IoT solution implementation and, 
therefore, exhibit a strategic managerial character. Detailed technological aspects, such as the necessary hardware or software, are not considered in this study.

Finally, our study offers ideas for future research. Against the background of the ongoing DC discussion and its advancement [11], our thoughts about the implementation of IoT solutions should be further discussed. Moreover, the temporal significance of competitive advantage through an effective IoT solution and the DC-related skills in the dynamic IoT market could be analyzed through a longitudinal study in order to assess their validity over time. Furthermore, a similar empirical study could be conducted with an international focus or in more detail in a certain industry, focusing on IoT solutions (for example, logistics, the automotive industry, the pharmaceutical industry and health care). Finally, technological aspects and skills for the implementation of an effective IoT solution should also be explored to complement our managerial-related results.

\section{References}

[1] Kille, C., M. Schwemmer, and C. Reichenauer, TOP 100 in European transport and logistics services: Market sizes market segments and market leaders in the European logistics industry, 2015th edn., DVV Media Group, Hamburg, 2015.

[2] Teece, D.J., "Dynamic Capabilities: Routines versus Entrepreneurial Action", Journal of Management Studies, 49(8), 2012, pp. 1395-1401.

[3] Xu, L.D., W. He, and S. Li, "Internet of Things in Industries: A Survey", IEEE Transactions on Industrial Informatics, 10(4), 2014, pp. 2233-2243.

[4] Andersen, M.P., G. Fierro, and D.E. Culler, "Enabling synergy in IoT: Platform to service and beyond", Journal of Network and Computer Applications, 81, 2017, pp. 96-110.

[5] Atzori, L., A. Iera, and G. Morabito, "The Internet of Things: A survey", Computer Networks, 54(15), 2010, pp. 2787-2805.

[6] Walton, N., The Internet as a Technology-Based Ecosystem: A New Approach to the Analysis of Business Markets and Industries, Palgrave Macmillan, London, 2017.

[7] Wang, C.L. and P.K. Ahmed, "Dynamic capabilities: A review and research agenda", International Journal of Management Reviews, 9(1), 2007, pp. 31-51.

[8] Luo, Y., "Dynamic capabilities in international expansion", Journal of World Business, 35(4), 2000, pp. $355-378$.

[9] Kale, P. and H. Singh, "Building firm capabilities through learning: The role of the alliance learning process in alliance capability and firm-level alliance success", Strategic Management Journal, 28(10), 2007, pp. 981-1000.

[10] Leischnig, A., Henneberg, S.C., Thornton, S.C., "Performing Configurational Analyses in Management Research. A Fuzzy Set Approach", 30th IMP Conference, 2014.

[11] Teece, D.J., "Towards a capability theory of (innovating) firms: Implications for management and policy", Cambridge Journal of Economics, 41(3), 2017, pp. 693-720.

[12] Bagozzi, R.P. and Y. Yi, "On the evaluation of structural equation models", Journal of the Academy of Marketing Science, 16(1), 1988, pp. 74-94.

[13] Barney, J.B., "Is the Resource-Based "View" a Useful Perspective for Strategic Management Research?: Yes", Academy of Management Review, 26(1), 2001, pp. 41-56.

[14] Barney, J., "Firm Resources and Sustained Competitive Advantage", Journal of Management, 17(1), 1991, pp. 99120.

[15] Bontis, N. and G. Kristandl, "Constructing a definition for intangibles using the resource based view of the firm", Management Decision, 45(9), 2007, pp. 1510-1524.

[16] Kraaijenbrink, J., J.-C. Spender, and A.J. Groen, "The Resource-Based View: A Review and Assessment of Its Critiques", Journal of Management, 36(1), 2010, pp. 349372

[17] Stauss, B., P. den Hertog, W. van der Aa, and M.W. de Jong, "Capabilities for managing service innovation: Towards a conceptual framework", Journal of Service Management, 21(4), 2010, pp. 490-514.

[18] Teece, D.J., G. Pisano, and A. Shuen, "Dynamic capabilities and strategic management", Strategic Management Journal, 18(7), 1997, pp. 509-533.

[19] Priem, R.L. and J.E. Butler, "Is the Resource-Based "View" a Useful Perspective for Strategic Management Research?", Academy of Management Review, 26(1), 2001, pp. 22-40.

[20] Kindström, D., C. Kowalkowski, and E. Sandberg, "Enabling service innovation: A dynamic capabilities approach", Journal of Business Research, 66(8), 2013, pp. 1063-1073.

[21] Inan, G.G. and U.S. Bititci, "Understanding Organizational Capabilities and Dynamic Capabilities in the Context of Micro Enterprises: A Research Agenda", Procedia - Social and Behavioral Sciences, 210, 2015, pp. 310-319.

[22] Ambrosini, V. and C. Bowman, "What are dynamic capabilities and are they a useful construct in strategic management?", International Journal of Management Reviews, 11(1), 2009, pp. 29-49. 
[23] Teece, D.J., "Strategies for Managing Knowledge Assets: The Role of Firm Structure and Industrial Context", Long Range Planning, 33(1), 2000, pp. 35-54.

[24] Eisenhardt, K.M. and J.A. Martin, "Dynamic capabilities: What are they?", Strategic Management Journal, 21(10-11), 2000, pp. 1105-1121.

[25] Teece, D.J., "A dynamic capabilities-based entrepreneurial theory of the multinational enterprise", Journal of International Business Studies, 45(1), 2014, pp. 8 37.

[26] Teece, D.J., "Dynamic capabilities and entrepreneurial management in large organizations: Toward a theory of the (entrepreneurial) firm", European Economic Review, 86, 2016, pp. 202-216.

[27] Winter, S.G., "Understanding dynamic capabilities", Strategic Management Journal, 24(10), 2003, pp. 991-995.

[28] Helfat, C.E., Dynamic capabilities: Understanding strategic change in organizations, 1st edn., Blackwell, Malden, MA, 2007.

[29] Beske, P., "Dynamic capabilities and sustainable supply chain management", International Journal of Physical Distribution \& Logistics Management, 42(4), 2012, pp. 372 387.

[30] Teece, D.J., "Explicating dynamic capabilities: The nature and microfoundations of (sustainable) enterprise performance", Strategic Management Journal, 28(13), 2007, pp. 1319-1350.

[31] Lin, Y. and L.-Y. Wu, "Exploring the role of dynamic capabilities in firm performance under the resource-based view framework", Journal of Business Research, 67(3), 2014, pp. 407-413.

[32] Lessard, D., D.J. Teece, and S. Leih, "The Dynamic Capabilities of Meta-Multinationals", Global Strategy Journal, 6(3), 2016, pp. 211-224.

[33] Katkalo, V.S., C.N. Pitelis, and D.J. Teece, "Introduction: On the nature and scope of dynamic capabilities", Industrial and Corporate Change, 19(4), 2010, pp. $1175-1186$.

[34] Helfat, C.E. and M.A. Peteraf, "Understanding dynamic capabilities: Progress along a developmental path", Strategic Organization, 7(1), 2009, pp. 91-102.

[35] Teece, D.J., Dynamic capabilities and strategic management: Organizing for innovation and growth, Oxford University Press, Oxford, 2009.

[36] Hodgkinson, G.P. and M.P. Healey, "Psychological foundations of dynamic capabilities: Reflexion and reflection in strategic management", Strategic Management Journal, 32(13), 2011, pp. 1500-1516.
[37] Porter, M.E., "Competitive advantage: creating and sustaining superior performance", New York: FreePress, 1985.

[38] Zahra, S.A., H.J. Sapienza, and P. Davidsson, "Entrepreneurship and Dynamic Capabilities: A Review, Model and Research Agenda*", Journal of Management Studies, 43(4), 2006, pp. 917-955.

[39] Covin, J.G. and D.P. Slevin, "Strategic management of small firms in hostile and benign environments", Strategic Management Journal, 10(1), 1989, pp. 75-87.

[40] Porter, M.E. and J.E. Heppelmann, "How smart, connected products are transforming competition", Harvard Business Review, 92(11), 2014, pp. 64-88.

[41] Iansiti, M. and K.R. Lakhani, "Digital Ubiquity: How Connections, Sensors, and Data Are Revolutionizing Business", Harvard Business Review, 92(11), 2014, pp. 9199.

[42] Lusch, R.F., S.L. Vargo, and M. Tanniru, "Service, value networks and learning", Journal of the Academy of Marketing Science, 38(1), 2010, pp. 19-31.

[43] Jeong, I., J.H. Pae, and D. Zhou, "Antecedents and consequences of the strategic orientations in new product development: The case of Chinese manufacturers", Industrial Marketing Management, 35(3), 2006, pp. 348-358.

[44] Fähnrich, K.-P. and M. Opitz, "Service Engineering Entwicklungspfad und Bild einer jungen Disziplin", in Service Engineering: Entwicklung und Gestaltung innovativer Dienstleistungen, H.-J. Bullinger and A.-W. Scheer, Editors. 2003. Springer Berlin Heidelberg: Berlin, Heidelberg.

[45] Friess, P., "Driving European Internet of Things Research", in Internet of Things: From Research and Innovation to Market Deployment, O. Vermesan and P. Friess, Editors. 2013. River Publishers: Aalborg.

[46] Kreutzer, R. and K.-H. Land, Digital Darwinism: Branding and Business Models in Jeopardy, Springer Berlin Heidelberg, Berlin, Heidelberg, 2015.

[47] Ben Letaifa, S., "The uneasy transition from supply chains to ecosystems", Management Decision, 52(2), 2014, pp. 278-295.

[48] Papert, M. and A. Pflaum, "Development of an Ecosystem Model for the Realization of Internet of Things (IoT) Services in Supply Chain Management", Electronic Markets, 27(2), 2017, pp. 175-189.

[49] Armstrong, J.S. and T.S. Overton, "Estimating nonresponse bias in mail surveys", Journal of Marketing Research, 14(3), 1977, pp. 396-402. 
[50] Homburg, C., J.P. Workman, JR., and H. Krohmer, "Marketing's Influence Within the Firm", Journal of Marketing, 63(2), 1999, pp. 1-17.

[51] Homburg, C., M. Artz, and J. Wieseke, "Marketing Performance Measurement Systems: Does

Comprehensiveness Really Improve Performance?", Journal of Marketing, 76(3), 2012, pp. 56-77.

[52] Zhou, K.Z., C.K. Yim, and D.K. Tse, "The Effects of Strategic Orientations on Technology- and Market-Based Breakthrough Innovations", Journal of Marketing, 69(2), 2005, pp. 42-60.

[53] Hakala, H. and M. Kohtamäki, "Configurations of entrepreneurial- customer- and technology orientation Differences in learning and performance of software companies", International Journal of Entrepreneurial Behaviour Research, 17(1), 2011, pp. 64-81.

[54] Gatignon, H. and J.M. Xuereb, "Strategic orientation of the firm and new product performance", Journal of Marketing Research, XXXIV, 1997, pp. 77-90.

[55] Bucklin, L.P. and S. Sengupta, "Organizing Successful Co-Marketing Alliances", Journal of Marketing, 57(2), 1993, p. 32.

[56] Karimi, J., T.M. Somers, and A. Bhattacherjee, "The Impact of ERP Implementation on Business Process Outcomes: A Factor-Based Study", Journal of Management Information Systems, 24(1), 2007, pp. 101-134.

[57] Ragin, C.C., ed., Redesigning social inquiry: Fuzzy sets and beyond, University of Chicago Press, Chicago, 2008.

[58] Fiss, P.C., "Building better causal theories: A fuzzy set approach to typologies in organization research", Academy of Management Journal, 54(2), 2011, pp. 393-420.

[59] Ragin, C.C. and S. Davey, "fs/QCA 2.5", 2009.

[60] Leischnig, A., Henneberg, S.C., Thornton, S.C., "Net versus combinatory effects of firm and industry antecedents of sales growth", Journal of Business Research, 69(9), 2016, pp. 3576-3583.

[61] Greckhamer, T., V.F. Misangyi, and P.C. Fiss, eds., The two QCAs: From a small-N to a large-N set theoretic approach.

[62] Ragin, C.C., Users guide to fuzzy-set/qualitative comparative analysis, University of Arizona, Arizona, 2008.

[63] Misangyi, V.F. and A.G. Acharya, "Substitutes or complements? A configurational examination of corporate governance mechanisms", Academy of Management Journal, 57(6), 2014, pp. 1681-1705.
[64] Schneider, C.Q. and Wagemann C., "Set-theoretic methods for the social sciences: A guide to qualitative comparative analysis", Cambridge Univ. Press, 2012.

[65] Ragin, C.C. and P.C. Fiss, "Net effects analysis versus configurations: An empirical demonstration", in Redesigning social inquiry: Fuzzy sets and beyond, C.C. Ragin, Editor. 2008. University of Chicago Press: Chicago.

[66] Nunnally, J.C., Pschometric theory, McGraw-Hill, New York, 1978.

[67] Bagozzi, R.P. and Y. Yi, "On the evaluation of structural equation models", Journal of the Academy of Marketing Science, 16(1), 1988, pp. 74-94. 